'Department of Geography and Environment, University of Dhaka, Dhaka, Bangladesh

*Corresponding author: mh20457@email.vccs.edu

\title{
LAND COVER CLASSIFICATION AND
}

: CHANGE DETECTION ANALYZING

\section{MULTI-TEMPORAL LANDSAT DATA: A CASE STUDY OF GAZIPUR SADAR, BANGLADESH BETWEEN 1973 AND 2017}

\begin{abstract}
This paper analyzed land cover changes in Gazipur Sadar - an important urban fringe of expanding Dhaka City, Bangladesh, by leveraging remotely sensed imageries between 1973 and 2017. Landsat images of1973, 1991, 2006, and 2017 were classified using widely-preferred supervised classification method. Compared against groundtruth data, the reported classification accuracy ranges from 85\% to 89\%. Our classified land cover maps reveal that built-up areas in Gazipur Sadar increased by 312.9\%, mostly replacing vegetation cover. An overall 199.7\% decrease of vegetative covers highlights on the degree of urbanization process and increasing population pressure faced by Gazipur Sadar over the past decades. The rapid decrease of vegetative cover only $57 \mathrm{sq} . \mathrm{km}$ remains out of $344 \mathrm{sq} . \mathrm{km}$ throughout the region, including the Sal (Shorea robusta) forest and other floral species - invaluable resources for biodiversity and ecosystem health, should be taken as 'alarming' situation by the local authority responsible for promoting and managing sustainable development goals. In that light, this study emphasizes on the need for a critical assessment of future development initiatives in the Gazipur Sadar area and suggests for maintaining acceptable tradeoffs between development and environmental protection.
\end{abstract}

KEY WORDS: land cover (LULC) classification, change detection, geographic information system, Gazipur Sadar (Bangladesh), urban, sustainability

CITATION: Md Arafat Hassan, Rehnuma Mahjabin, Md Rakibul Islam, Sakib Imtiaz (2019) Land Cover Classification and Change Detection Analyzing Multi-Temporal Landsat Data: A Case Study of Gazipur Sadar, Bangladesh between 1973 and 2017. Geography, Environment, Sustainability, Vol.12, No 1, p. 104-118

DOI-10.24057/2071-9388-2018-12

\section{INTRODUCTION}

Man is leaving his mark on every part of the Earth surface and altering the physical attributes at a rapid rate with his activities (Lambin et al. 1999). The changing ecosystem has been a matter of concern in the global studies (Dixon et al. 1994; Ojima et al. 1994), as harmful human activities are constantly changing the natural land cover, which in turn, affect the carbon cycle and disturb the balance of carbon dioxide $\left(\mathrm{CO}_{2}\right)$ in the atmosphere (Alves and Skole 1996). In the developing countries, urban growth, coupled with 
the industrial development and the transformation of agricultural land into built-up areas are some of the leading causes of vegetation loss (Shalaby and Tateishi 2007). Land cover is supposed to be the natural and manmade vegetation cover but at present, it includes human settlements, infrastructure, industries space without vegetation and water and other natural and anthropogenic features (Klimanova et al. 2017). Additionally, the rapid alteration of land cover have raised a huge number of issues such as the adverse effect on the relationship between biosphere and atmosphere, extinction of a diverse range of species and deteriorating soil condition (Meyer and Turner 1994). Conservation of the existing vegetation areas and regeneration of the lost vegetation cover is now essential for maintaining the ecological balance and improving the health of the environment (Xin et al. 2011). Conservation and regeneration initiatives require the accurate measurement and mapping of areas experiencing vegetation loss. Tropical regions are covered with large forest areas that contribute to the protection from climate change, by absorbing billions of tons of $\mathrm{CO}_{2}$, and can play an important role in reducing the environmental externalities due to the degradation of forest areas (Canadell et al. 2008).

Bangladesh is a developing country and accommodates a huge population with in a very small geographic area. The connection between population and environment was not well understood until recent times. At present, the strong inter-relationship between the population and the natural environment is known to all. This issue came into attention especially after the RIO declaration in Brazil (1992) and 1994 Cairo conference on global population (World Bank 2017). Bangladesh has 162,951,560 people living in an area of $147,570 \mathrm{~km}^{2}$ and with a population growth rate of 1.1\% (World Bank Data 2016). This huge population has different needs and consumption behavior, which create excessive pressure on the environment. Requirements of food and housing facilities triggers deforestation (Rahman 1994). Moreover, rapid urbanization has caused a decrease in the forest area, agricultural land and water bodies (Giri et al. 1996). Many agricultural and vegetation covered areas are being transformed into built up and infrastructural constructs (Quasem 2011). Hasan et al suggested that the country has experienced a decrease of about 1.12 million ha of vegetation area, comprising agricultural and mangrove forest areas, from the year 1976 to 2010.However, the increase of non-agricultural land during this period was 1.22 million ha (Hasan et al. 2013). According to Food and Agriculture Organization, the annual deforestation rate of Bangladesh is $0.2 \%$, one of the high deforestation rates in the developing countries (Fao 2015).

Gazipur district is located at the Northern part of Dhaka city and is one of the nearest districts from the capital city (Bangladesh Bureau of statistics 2011). In the past, the region was a part of a deep forest named as Vawal Pargana. The district has an area of $1806.36 \mathrm{sq}$. km with $17.53 \mathrm{sq} . \mathrm{km}$ of wetlands and $273.42 \mathrm{sq} . \mathrm{km}$ of forest area. Around 34,03,912 people live in this district, having a density of 1884 people per sq. $\mathrm{km}$ and a population growth rate of 5.2\% (Bangladesh Bureau of Statistics 2011). The area is most suitable for agricultural work and the majority of the people are involved with agro-based economic activities. But with the increasing pressure of population and socioeconomic changes, the area can characterized of having sharp urbanization and industrialization rates (Islam 2013).

Sal forest (also known as Madhupur forest) is an asset of Bangladesh, which spreads across Dhaka and Gazipur districts. Gazipur disctrict contains around $86 \%$ of the Sal forest of the country. Human activities like land overuse, deforestation, urbanization, agricultural and industrial activities are creating a threat for this forest. Gazipur Sadar Sub-district used to contain 20\% of this forest but the forest area is decreasing gradually (Fazal et al. 2015). Gazipur Sadar Sub-district is becoming the new industrial hub of the country due to its proximity to the capital city and the enhanced transport facilities. However, this development is having a negative impact on the forest area in this region. Industries are growing exponentially at the expense of forest land and are causing heavy pollutions with adverse environmental consequences (Dong et al. 1997). 
As a developing country, the application of land use and other relevant geographic data is quite scarce in Bangladesh. For a developing country, remote sensing images can be the most reliable source of an updated land use or land cover data (Dong et al. 1997; Yang 2002). Updated and accurate data can help in many ways to compare scenarios at different temporal scales (seasonal, monthly or annually) and can also help devising plans and policies for the future development (Alpha 2003). Therefore, this paper employed remote sensing data for detecting the land cover change.

This paper aims to analyze the changing pattern of vegetation cover in Gazipur Sadar Upazila. This analysis attempts to give a clear picture of the present day vegetation condition and to help understand the rate and cause of the changing patterns.

\section{STUDY AREA}

Gazipur Sadar Sub-district is located between latitudes of $23^{\circ} 53^{\prime}$ and $24^{\circ} 11^{\prime} \mathrm{N}$ and longitudes from $90^{\circ} 20^{\prime}$ to $92^{\circ} 30^{\prime} \mathrm{E}$ (Fig. 1). The total area is about $446.38 \mathrm{sq}$. km, consisting a total population of 866,540 and a population density of about 1,941 people per sq. km. Gazipur Sadar Sub-district is administratively made up of eight unions: Bashan, Baria, Gachha, Kasimpur, Kaultia, Konabari, Mirzapur, Pubail (Bangladesh Bureau of Statistics 2011).
The Turag River flows past over the western part of the city and the Balu River flows along the eastern side. Other notable waterbodies are the Labandanga River, the Salda River, and the Tongi canal. The Sub-districtis surrounded by the Sreepur Sub-district in its north, Rupganj Sub-district from south to east and Savar Sub-district from south to west.

Gazipur Sadar is a part of Madhupur tract, which is a terrace having Dhaka in the south and Jamalpur and Mymensingh districts in the north. The total area of the terrace is about 4,244 sq. $\mathrm{km}$ and is slightly elevated than the nearby floodplains, the area is also subjected to occasional tectonic activities (Brammer 1996). There is a similarity between Gazipur alluvium and Brahmaputra floodplain alluvium but the clay is called Madhupur clay. The area has slopes and low-level circular ridges in different places (Rashid, 2008).Huge range of soils can be found in this area such as the Red-Laterite soil and Pleistocene clay. $(\mathrm{FAO}, 1988)$

The climatic condition of the Gazipur districtis similar to a tropical climate. The area has a moderate temperature and rainfall of 25.8 ${ }^{\circ} \mathrm{C}$ and $2036 \mathrm{~mm}$ respectively. The highest temperature can be recorded in the month of May and the lowest temperature can be recorded in the month of January.

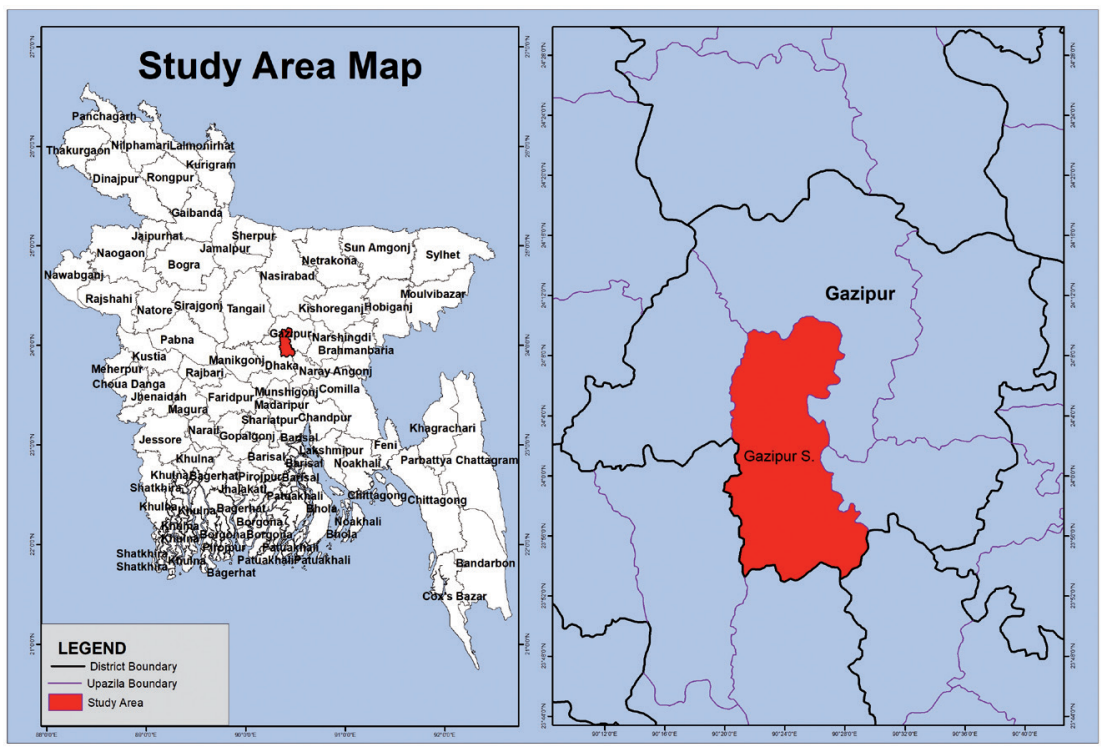

Fig. 1. Geographic location of the study area 


\section{DATA AND METHODOLOGY}

Remote sensing data can give a perfect image of land use change in different sections of the land (Klimanova et al. 2017). This study used multi-temporal remotely sensed images from Landsat 5, 7, and 8, between the years 1973 and 2017. Last 40 years have been very crucial for the forest land of Gazipur, as from 1989 to 2009 about 20.29\% forest area have decreased (Yesmin et al. 2014). We chose four years that can represent the past decadal variations of land cover in the area. The Landsat database made for this research was constructed by four sets of data, they are Landsat images from MSS (05 December 1973), Path/ Row: 147 / 043 for 1973, TM (26 November 1991) for 1991, ETM+ (21 December 2006) for 2006 and OLI (07 December 2017) for 2017. In the Landsat image selection process, 'less than $10 \%$ cloud' cover was a criterion for ensuring the accuracy of the classified images. Therefore, it was not possible to find the images of the same month for every year. In the Gazipur district, November to February is winter and less cloudy (Uddin and Gurung 2010). So, Landsat data were selected from November to February to minimize the seasonal and cloud cover influences on the acquired images. ERDAS Imagine (Leica Geosystems 2006) and ArcGIS (ESRI 2005) are both very important tools for land cover assessments and hence, for this paper both of the software were used for data processing and analysis. First of all, geometric correction was performed as the data needed to be properly coordinated to adjust for the tectonic movements. For executing geometric correction, we selected a reference image of Landsat TM for the year 2017. 80 ground control points were taken at random that were scattered over the study area for acquiring the perfect geometrically corrected image. The root means square error (RMSE) was very low from 0.25 to 0.45 pixel. All the data were resampled to $30 \mathrm{~m}$ pixel size, using the nearest neighbor method. The coordinate system of the image was set as the Bangladesh Transverse Mercator system (BTM). Different sources are tested to identify correct training area and to perform the accuracy assessment.
Atmospheric correction was also performed to reduce the atmospheric dust, solids, and liquids. Atmospheric correction was done following López-Serrano et al. (2016).

\section{Image classification}

The classification of image is partly affected by the method of Anderson Scheme Level 1. (Anderson et al. 1976). The image classification was based on broad categories of land cover and spatial resolution with a range of $30 \mathrm{~m}$ to $79 \mathrm{~m}$. Classification was carried out based on the four broad land cover categories (shown in Table 1), vegetation cover, waterbody, built-up area and agricultural land.

A minimum of 70-80 samples were collected to train each of the classes and if the sample was big enough, about 200 to 400 pixels were taken. Every land use category consisted of about 15-20 subclasses to get the perfect accuracy. The training classes underwent several stages like merging, deletion or renaming. A model is built from the training data, which is then run to obtain the final classified image. Despite the caution taken while devising the model, errors could be found in the final output. Common errors of classification include the difficulties arising while distinguishing between the agricultural grasslands and healthy vegetation (Bolstad and Lillesand 1991).

The land cover change for each of the classes was calculated using the following formula (Islam et al. 2017):

Magnitude = magnitude of the new year magnitude of the previous year

Percentage change of a particular class was calculated by dividing the change in area by the area in the base year (primary year), and multiplied by 100 .

For calculating the rate of yearly change for every land cover class, the percentage change was divided by the number intervening years. Calculated data are shown in Fig. 8. 
Table 1. Land cover classification scheme

\begin{tabular}{|c|c|}
\hline Land use cover types & Description \\
\hline Water body & River, permanent and temporary open water, reservoir. \\
\hline Vegetation & Sal forest, deciduous forest, mixed forest,bamboo \\
\hline Agricultural land & Crop, open field, fallow land, mixed forest lands \\
\hline Built-up & Residential, commercial, industrial,road and streets \\
\hline
\end{tabular}

Table 2. Summary of land cover classification data between 1973 and 2017 (area in sq km)

\begin{tabular}{|c|c|c|c|c|c|c|c|c|}
\hline $\begin{array}{c}\text { Land cover } \\
\text { types }\end{array}$ & $\begin{array}{c}1973 \\
\text { Area }\end{array}$ & $\begin{array}{c}1973 \\
\text { (in \%) }\end{array}$ & $\begin{array}{c}1991 \\
\text { Area }\end{array}$ & $\begin{array}{c}1991 \\
\text { (in \%) }\end{array}$ & $\begin{array}{c}2006 \\
\text { Area }\end{array}$ & $\begin{array}{c}2006 \\
\text { (in \%) }\end{array}$ & $\begin{array}{c}2017 \\
\text { Area }\end{array}$ & $\begin{array}{c}2017 \\
\text { (in \%) }\end{array}$ \\
\hline Vegetation & 145.63 & 46.93 & 84.85 & 37.32 & 24.15 & 6.99 & 57.76 & 16.72 \\
\hline Built-up area & 0.0948 & 0.02 & 13.17 & 3.83 & 133.79 & 38.74 & 137.79 & 39.91 \\
\hline Water bodies & 37.59 & 10.88 & 58.21 & 16.85 & 1.62 & 0.47 & 36.83 & 10.66 \\
\hline Agricultural land & 162.03 & 42.17 & 189.13 & 42 & 185.81 & 53.8 & 112.99 & 32.71 \\
\hline
\end{tabular}

Table 3. Classification accuracies in percent (Producers-Users accuracy)

\begin{tabular}{|c|c|c|c|c|c|c|c|c|}
\hline Land cover class & $\begin{array}{c}1973 \\
\text { producer's }\end{array}$ & $\begin{array}{c}1973 \\
\text { user's }\end{array}$ & $\begin{array}{c}1991 \\
\text { producer's }\end{array}$ & $\begin{array}{c}1991 \\
\text { user's }\end{array}$ & $\begin{array}{c}2006 \\
\text { producer's }\end{array}$ & $\begin{array}{c}2006 \\
\text { user's }\end{array}$ & $\begin{array}{c}2017 \\
\text { producer's }\end{array}$ & $\begin{array}{c}2017 \\
\text { user's }\end{array}$ \\
\hline Water bodies & 88.5 & 85.5 & 98 & 77 & 93.5 & 100 & 84.3 & 100 \\
\hline Built-up area & 90.3 & 100 & 75.4 & 98.5 & 87.5 & 87.4 & 90.5 & 98.5 \\
\hline Vegetation & 82 & 72.3 & 95.5 & 92.3 & 85.5 & 88.5 & 87.5 & 82.3 \\
\hline Agricultural land & 74.4 & 76.5 & 89.5 & 83.5 & 85.3 & 92.5 & 82.3 & 73.5 \\
\hline
\end{tabular}

\section{Accuracy Assessment}

Mixed pixel or pixel with the same color always create a problem (Lu and Weng 2005). The sample for this training site has been demarcated by area of interest or $\mathrm{AOI}$ which also gives local knowledge. For validating the classified images with the real life features, different accuracy assessments were performed. To asses 1973, 1991 and 2006 data, a total 120 pixels were developed through stratified random sampling method. These pixels were used to compare with the features in a high-resolution topographic map of Gazipur district. For 2017, the reference data collected from the field were used. For this purpose, a total of 90 ground data pointes were collected and used to calculate the classification accura- cy. Then, the accuracy of each classification was evaluated in terms of the overall and producers-users accuracy as well as the kappa coefficient.

\section{RESULTS AND DISCUSSION}

The pattern of land cover change during 1973 to 2017 is shown in Fig. 2. During this period, Gazipur Sadar has shown a rapid land use change. The changes in vegetation cover are illustrated in Fig. 4, 5, 6 and 7. In the year 1973, a noticeable amount of vegetation cover (145 sq. $\mathrm{km}$ ) can be observed in the northern part of the Sadar Sub-district, which comprised of $47 \%$ of the total land cover and extended along the eastern border of the area. This year was during the period after independence 
when the industrial growth of the country was slow. Gazipur Sadar at that time was a fully agrarian society (Lesser 1888).

Fig. 2 shows that the agricultural land is covering the central part of the Gazipur Sadar sub-district and some patches of agricultural lands are visible in the northern part, inside the vast vegetation cover. The agricultural land covered an area of $162 \mathrm{sq}$. $\mathrm{km}$ in 1973, which was $42 \%$ of the total land cover. The waterbodies mainly covered the eastern and western borders of the area. After the independence of Bangladesh in 1971, most of the settlements in the area were observed to be small and negligible (only $0.02 \%$ of the land cover). The changes between 1973 and 1991 is quite evident as the amount of vegetation cover in the northwestern part had almost vanished completely (Fig. 5). It was the first sign of massive human activity in Gazipur. The northwestern part of the region has turned vegetation into agricultural land and thus, vegetation cover decreased from $47 \%$ to $37 \%$. The scattered vegetation that can be seen in midst of the agricultural land was mainly planted by the humans. Rapid development leading to the uncontrolled expansion of the built up area has resulted in the filling up of rivers indifferent parts of the Turag and Balu river.
Fig. 2 shows that $38 \%$ of the total areas was the built-up area in 2006. Scattered vegetation of the central part had been destroyed and infrastructure was developed in that area. The natural forest of the northeastern part was disturbed badly due to urban sprawl and other construction activities. Dhaka city would be expanding and developing towards the Gazipur and Narayangang (Dewan et al. 2009). Our results and findings support this prediction. A noticeable fact is that in the year 2006, a patch of the built-up area can be observed expanding from south to north in a linear pattern. This was actually the newly developed industrial territory in Gazipur Sadar. Fast-growing industries were the main reason behind the loss of agricultural land, wetlands, and vegetation in this area. The change was markedly rapid from 2004 to 2010. Another interesting fact is that the parts of the Turag River and Balu River were significantly filled up and turned to temporary agricultural land in 2006. By 2017, this newly developed agricultural land in 2006was destroyed by the built-up area. The river flows and the vegetation beside these areas, which together had formed an ecosystem itself, was totally removed and replaced by settlements. In 2017, the Institution of Human Rights and Peace for Bangladesh filled a petition against these encroachments that comprised of about 30 illegal structures along the coast of Turag River. According to the lawyers,

\section{Land Cover Percentage}

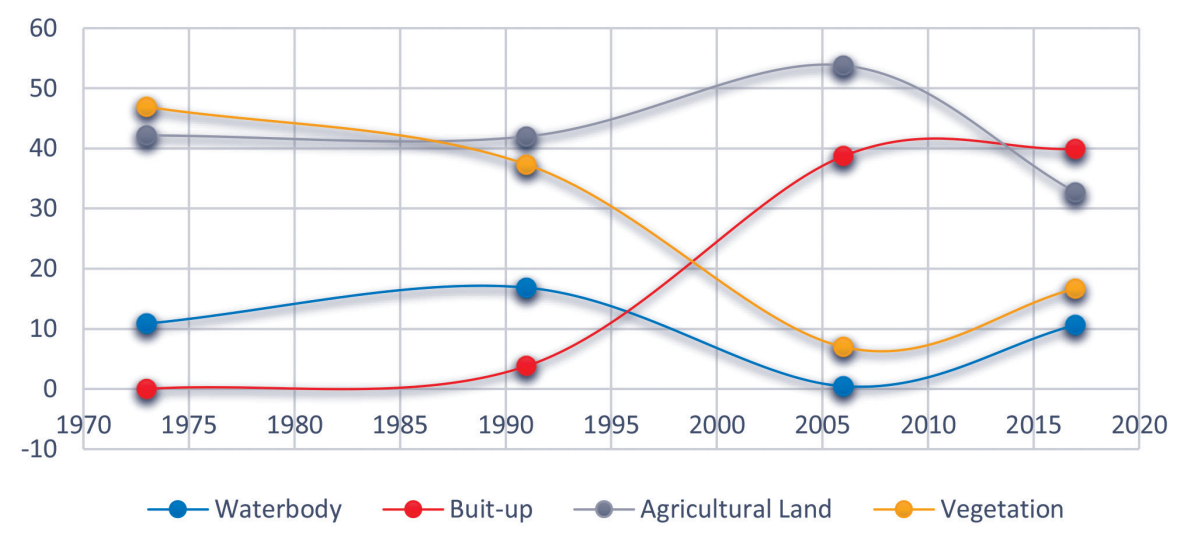

Fig. 2. Temporal comparison between the amount of vegetation coverage and other land cover classes 
government agencies had built pillars and walkways near the banks of the river and the land grabbers took this opportunity to grab the surrounding land and build illegal structures (The Daily Star 2017).

In the late 1990s, the area started to develop industrially and thus, instigating a rapid change that had mainly focused on the economic development and not on the health of the environment. With the ever-increasing population, the built-up area began to rise. In Fig. 3, it is evident that the area covered by vegetation and waterbody classes have experienced a sharp declining pattern. According to Fig. 3, the amount of vegetation coverage was $145 \mathrm{sq} . \mathrm{km}$ in 1973 , which with a decreasing rate of $72 \%$ was reduced to 84 sq. km in 1991. Similarly, further vegetation clearing was observed with a $250 \%$ decrease rate in the next 15 years, which reduced the figure to just $24.15 \mathrm{sq}$. $\mathrm{km}$ by 2006 . These rates show that the diminishing of vegetation coverage had proliferated throughout the years and also increased progressively over the passing years.

People in this region had encroached illegally when there was no fixed demarcation of the forests (Rahman, 2016). The national forest policy was adopted by the government of Bangladesh in 1979 with an emphasis on forest protection. However, the policy had partially failed because of lack of prioritization on the participation of the local people. The present forest policy had been continuing from 1994, which is much broader and well-constructed than the previous one (Millat-e-Mustafa 2002). But the impact of this policy was evident after the year 2000 .

At the same time, there was a Forestry sector project (1997-2004), which was implemented with the concept of protected forest area, buffer zones and participatory tree plantation (Salam et al. 2004). After the effective stage of vegetation conservation, it is evident that the vegetation coverage has increased by about 315\% (Fig. 8) which resembles Salam's work

Population explosion and the expansion of the built-up area can be identified as the two of the main reason behind the diminishing vegetation coverage. From 1973 to 1991, lots of construction activities were carried out in the region, such as the garments industries. Built up area increased from 0.02 to $13 \mathrm{sq}$. $\mathrm{km}$ that was a drastic change but as mentioned earlier, there was no observable pattern in settlement and built up area. The houses of dwellers were scattered all over the region. Moreover, there was no strong base or foundation of these types of houses. These were mainly temporary Jhupri (shack) type of settlement structures. In 2006, the amount of built-up area had remained same (133 sq. km) as the rate of development or the growth of builtup area gets stability with stable population increase. In the succeeding years, the amount of built up area rose to 137 sq.km, which reiterate the fact that over the past 11 years the built-up area had reached a stable condition or is close to reaching the peak of its growth. During the initial stage,

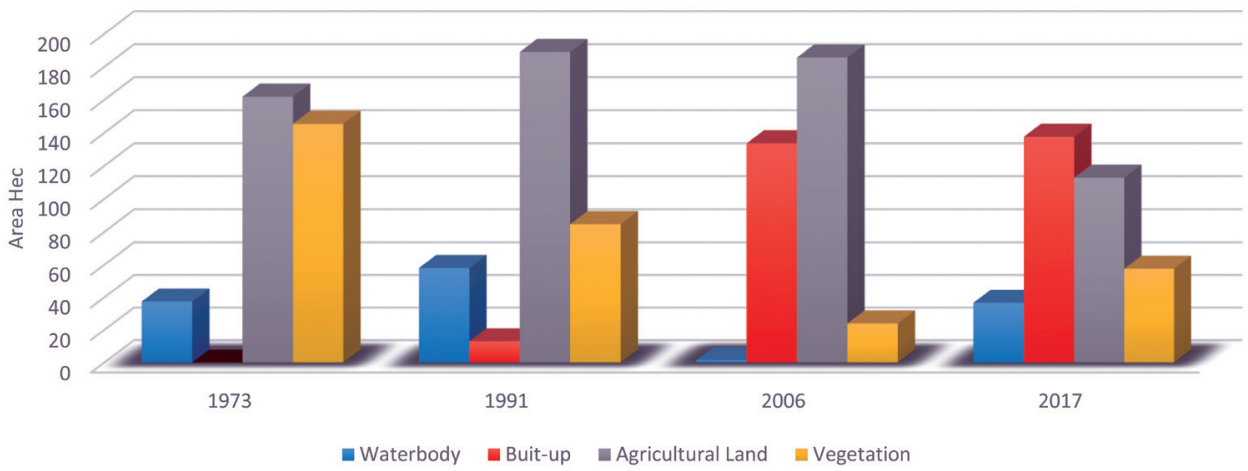

Fig. 3. Land cover in Gazipur Sadar 


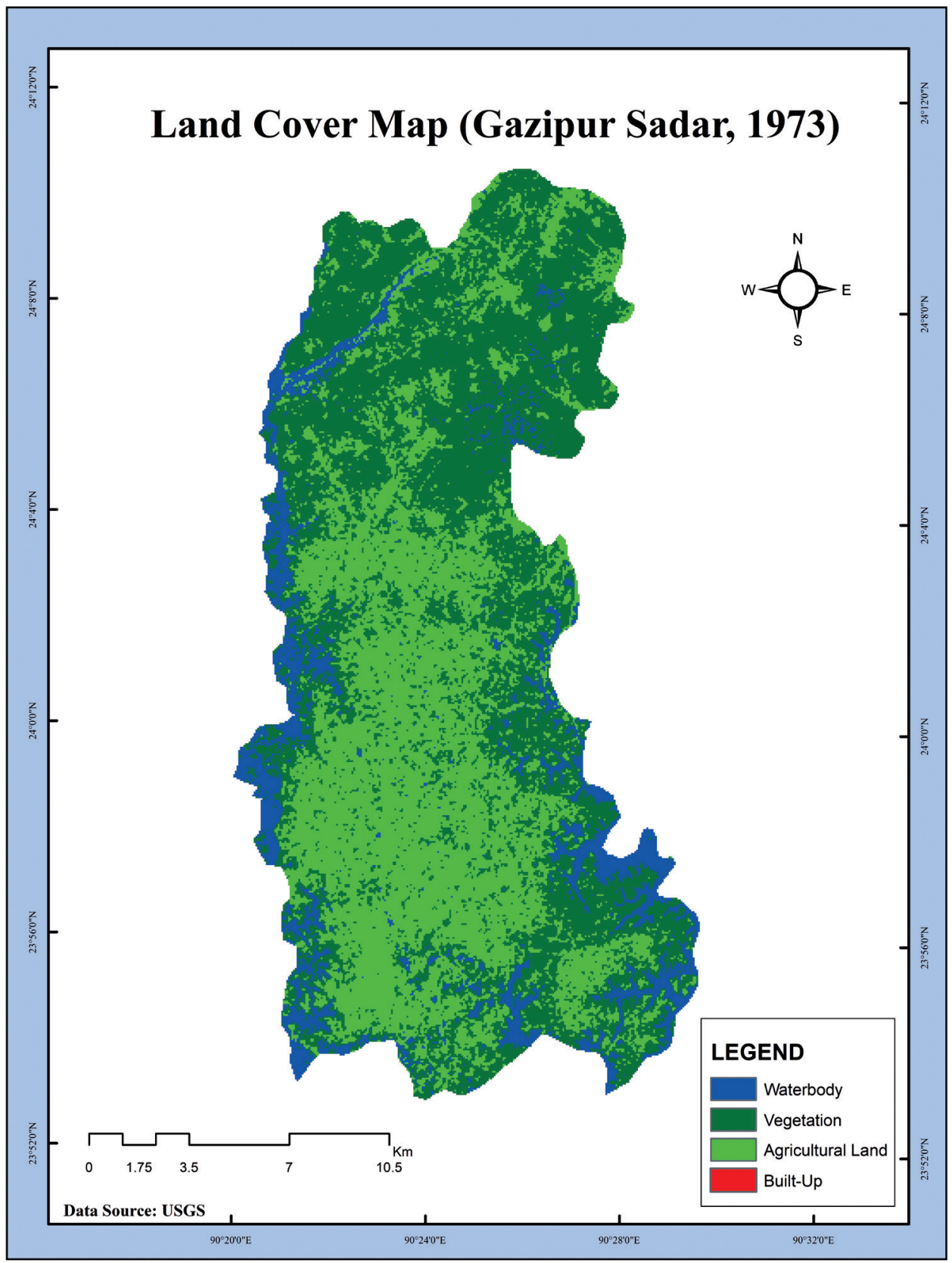

ய

r

Fig. 4. Land cover map of Gazipur Sadar, 1973 


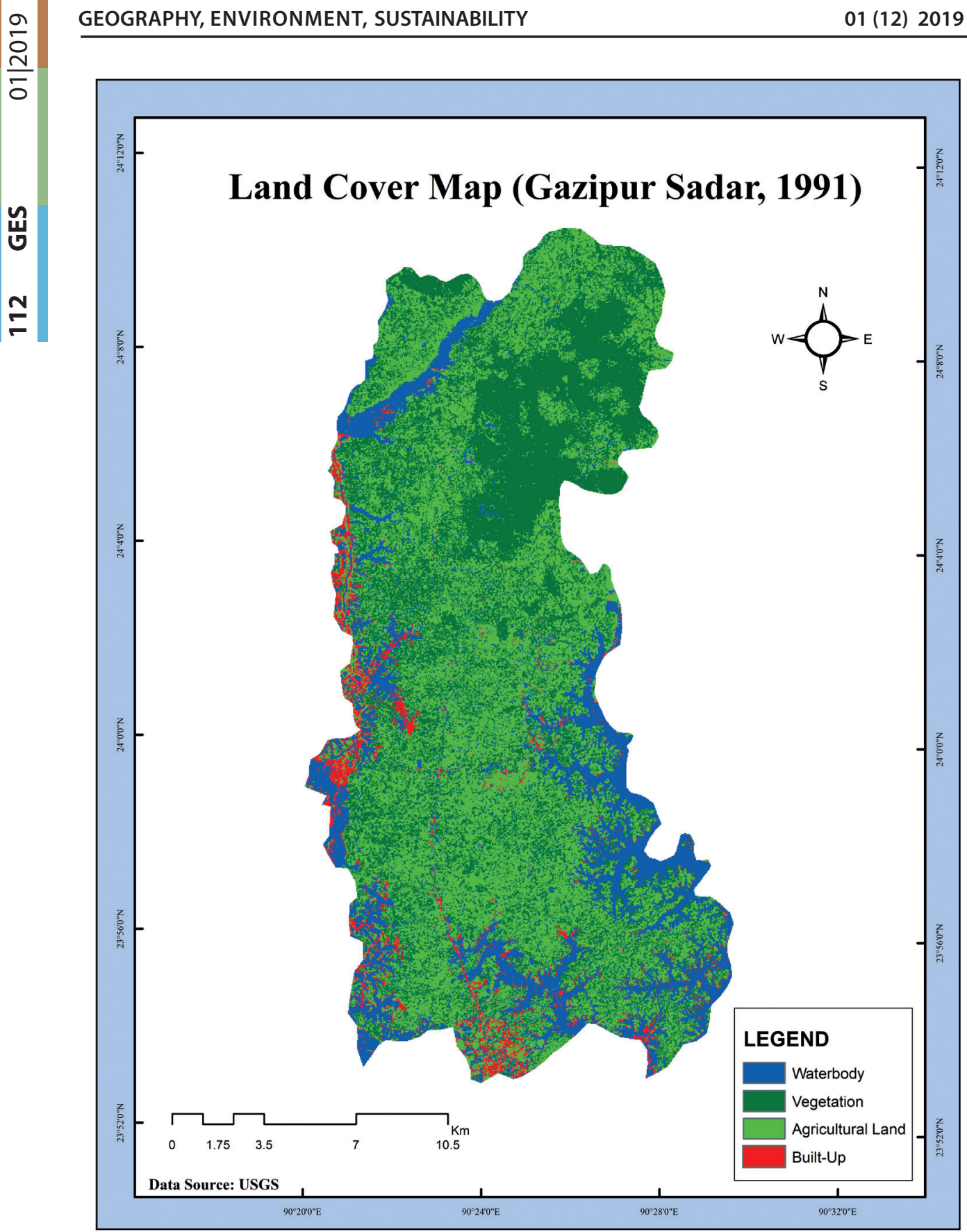

Fig. 5. Land cover map of Gazipur Sadar, 1991 


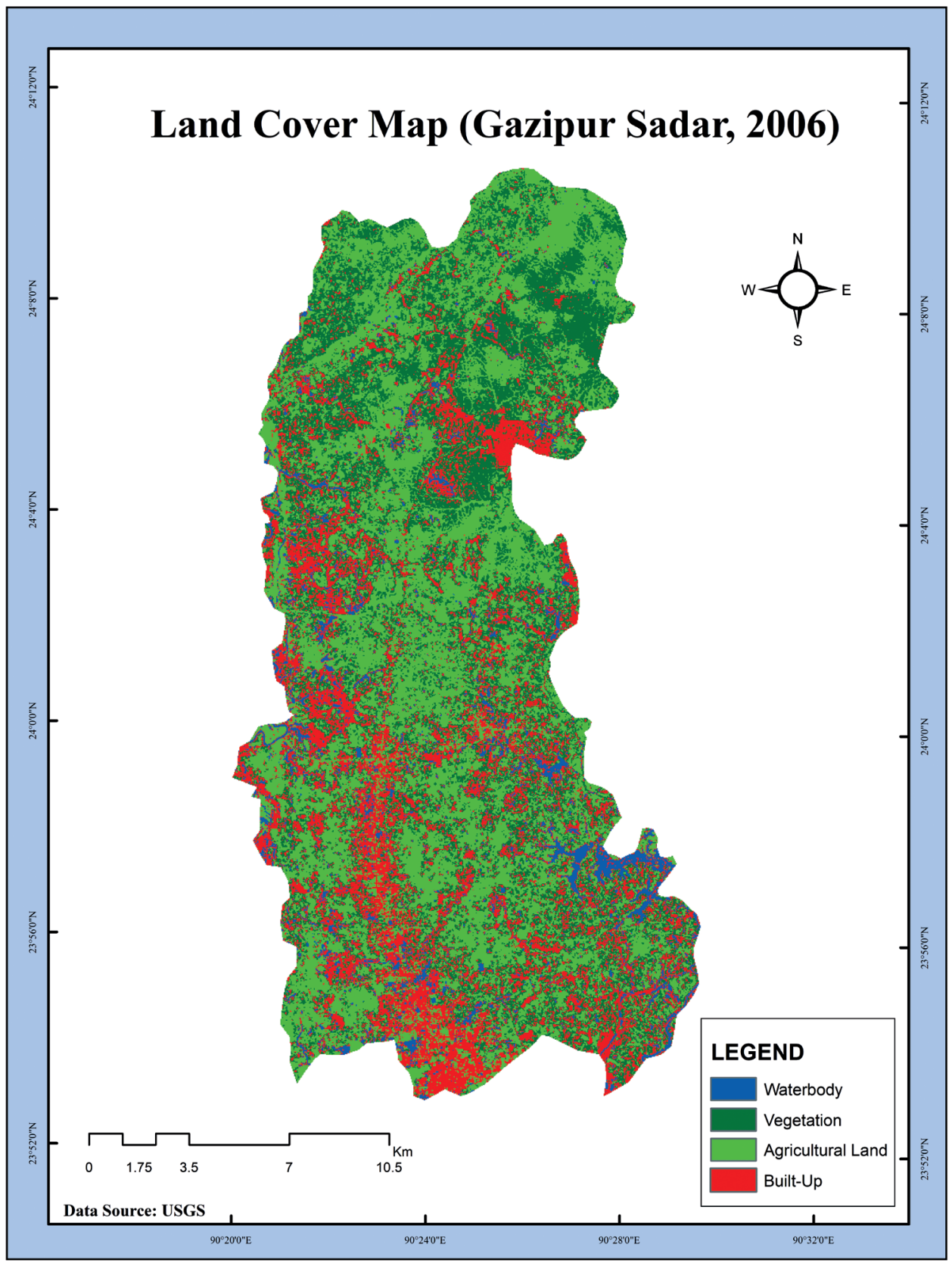

岕

$\stackrel{m}{r}$

Fig. 6. Land cover map of Gazipur Sadar, 2006 


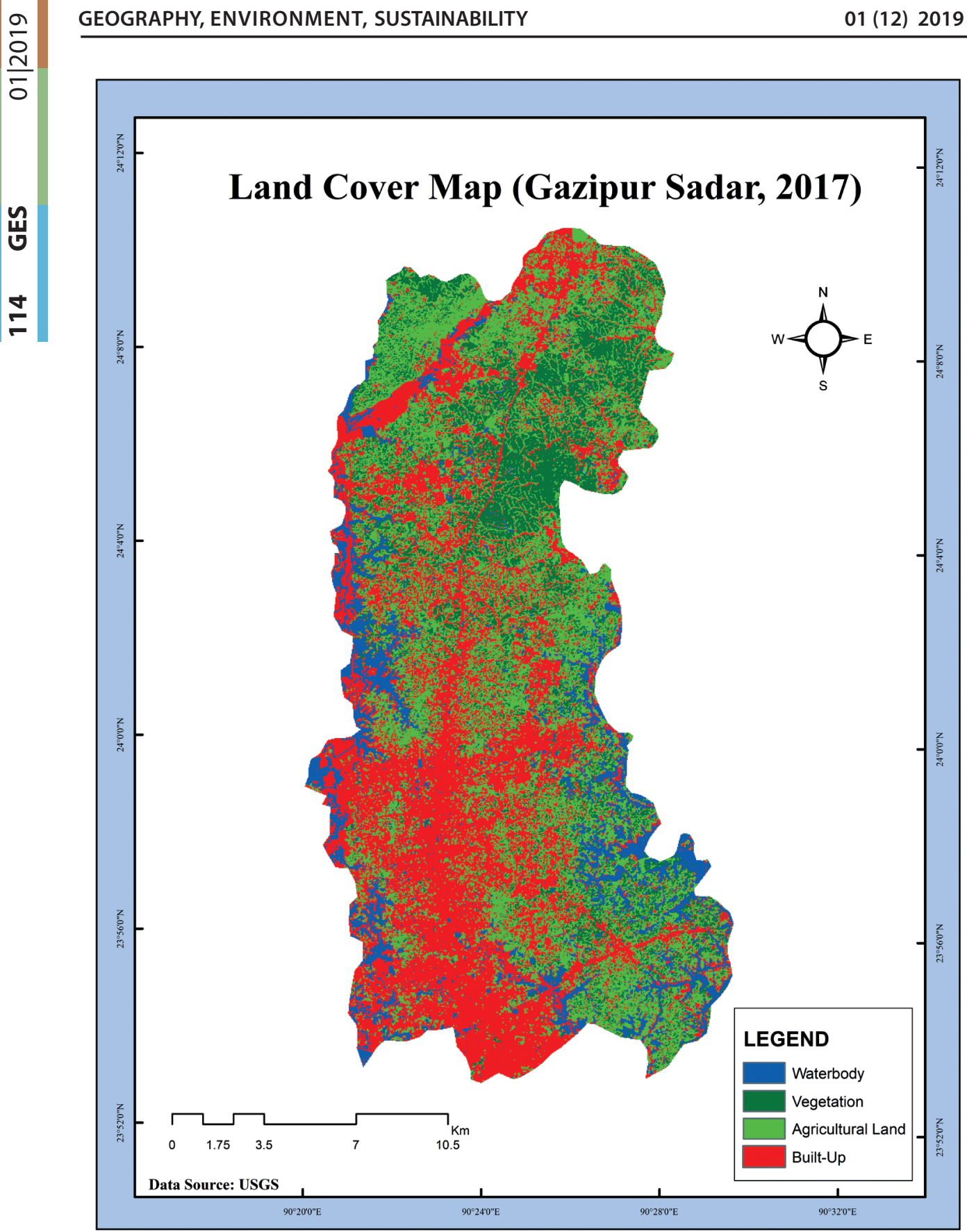

Fig. 7. Land cover map of Gazipur Sadar, 2017 


\section{Relative Changes in the Percentage of Land Cover}

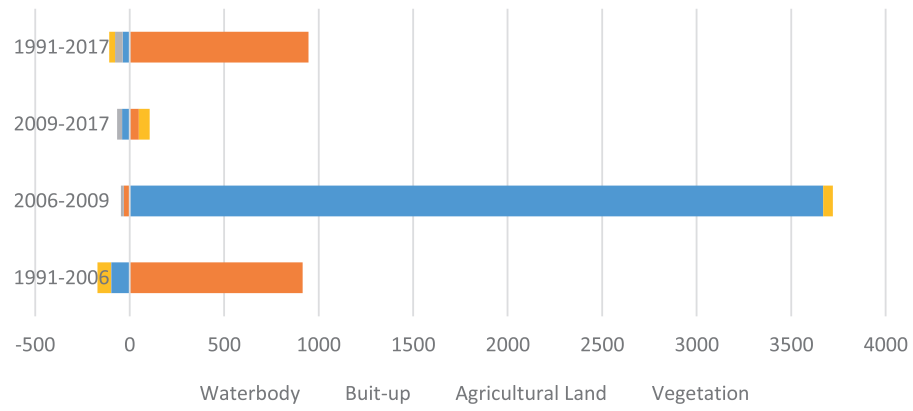

Fig. 8. Relative changes in land cover (\%) in Gazipur Sadar

the increase of the agricultural land was a major reason behind the clearing of natural vegetation. This was because the region's economy was totally dependent on agriculture and therefore, a growth from 162 sq. $\mathrm{km}$ to $189 \mathrm{sq} . \mathrm{km}$ in the agricultural land can be observed from 1973 to 1991.

However, with the gradual development of industries in Gazipur, the city has now become an important industrial hub of Bangladesh. BSIC (Bangladesh Small and Cottage Industries Corporation) area was developed that further promoted industrialization along the coast of the Turag River (Sultana et al. 2012). After the development of the industries, the agricultural growth had slowed down in the year 2006. The agricultural land comprised of $185 \mathrm{sq}$ $\mathrm{km}$ and was drastically reduced to $72 \mathrm{sq}$. $\mathrm{km}$ by 2017. Another reason for this drastic change is that the lands previously used for agriculture are now being used for fish cultivation, which is presently a very popular practice in this area. Adopting the concept of integrated farming, many farmers are using the agricultural lands for fish farming and are even destroying the vegetation coverage for the same purpose. Although, it is a profitable initiative for the economy of the region, sometimes poor maintenance poses a challenge for environmental sustainability (Ferdous et al. 2001).

\section{CONCLUSION}

This paper analyzed the changes in land cover in Gazipur Sadar Sub-district using Landsat data between 1973 and 2017.
While historically Gazipur district has been well-known for its rich forest resources, significant LULC changes are taking places due to the rapid urbanization over the past few decades. The present trend in LULC change indicates the negative impact of human activities on the vegetation coverage. Over the past 44 years, vegetation coverage had diminished by $199.7 \%$ - an alarming issue for the environment of the area. Industrial pollution, growth of builtup areas, encroachment of rivers and waterbodies along with the exploitation of existing resources are having devastating consequences to the vegetation coverage. Considering the present condition, conservation of vegetation coverage is necessary and should be one of the key prioritizing issues. Rules and regulations must be strictly followed prior to the establishment of settlements or industrial projects. Implementation of existing policies pertaining to the reservation of forest is essential and appropriate policies for the conservation vegetation coverage and valuable land must be introduced by the concerned authorities. Moreover, it is the dweller's duty to maintain the natural environment and the intricate balance between economic growth and environmental health, for ensuring a sustainable development in the region. For this reason, participatory programs with a bottom up approach are highly recommended. The management of vegetation coverage and the efficacy of any conservation initiatives will depend on the overall role-play of the general people. More research and the collection of adequate data will help build the conscious- 
ness of the public. Remote sensing data aid in acquiring reliable images of the study area that can be used for further analysis, especially when there is a limited access to data or maps. Careful analysis can help maintaining the accuracies of classifications to over $85 \%$. Hence, satellite images can be an effective data source for environmental analysis.

\section{ACKNOWLEDGEMENTS}

Authors wish to thank the unknown referees for their valuable suggestions, which improved the final form of this paper.

\section{REFERENCES}

Alphan H. (2003). Land use change and urbanization in Adana, Turkey. Land Degradationand Development, 14(6), 575-586.

Alves D.S. and Skole D.L. (1996). Characterizing land cover dynamics using multi-temporal imagery. International Journal of Remote Sensing, 17(4), 835-839.

Anderson R., Hardy E. E., Roach J.T., and Witmer R.E. (1976). A land use and land cover classification system for use with remote sensor data. USGS Professional Paper 964. Washington, DC.

Bangladesh Bureau of Statistics (BBS) and informatics division (SID) Ministry of planning government of the people's republic of Bangladesh (2011).

Bangladesh (1996). Int. J. Remote Sens., 17, 2749-2759.

Bolstad P.V. and Lillesand T.D. (1991). Rapid Maximum Likelihood classification. Photogrammetric Engineering \& Remote Sensing, 57, 67-74.

Center for Urban Studies (CUS), National Institute of Population, Research and Training (NIPORT), \& Measure Evaluation (2006). Slums in urban Bangladesh: Mapping and census, 2005. Dhaka, Bangladesh/Chappell Hill, USA.

Brammer H. (1996). The Geography of the Soils of Bangladesh, Dhaka Bangladesh, University Press: 1996.

Canadell J.G and Raupach M.R. (2008). Managing Forests for Climate Change Mitigation. Science, 5882(320), pp. 1456-1457.

Dewan A.M., Yamaguchi Y. (2009a). Using remote sensing and GIS to detect and monitor land use and land cover change in Dhaka Metropolitan of Bangladesh during 1960-2005. Environ. Monit. Assess., 150, 237-249, doi: http://dx.doi.org/10.1007/s10661-008-0226-5

Dewan A.M., Yamaguchi Y. (2009b). Land use and land cover change in Greater Dhaka, Bangladesh: using remote sensing to promote sustainable urbanization. Appl. Geogr. 29, 390-401, doi: http://dx.doi.org/10.1016/j.apgeog.2008.12.005

Hundreds of acres of forest, crop land, water bodies destroyed (August 6, 2013). Dhaka Mirror.

Dixon R.K., Brown S. Houghton R.A., Solomon A.M., Trexler M.C., and Wisniewski J. (1994). Carbon pools and flux of global forest ecosystems. Science, 263, pp. 185-190. 
Dong Y., Forster B., and Ticehurst C. (1997). Radar backscatter analysis for urban environments. International Journal of Remote Sensing, 18(6), pp. 1351-1364.

Environmental System Research Institute (2005). Using ArcGIS. Redlands, USA: ESRI.

Fazal S.A., Bhuiyan M.A.H., Chowdhury M.A.I. and Kabir M.M. (2015). Effects of Industrial Agglomeration on Land-Use Patterns and Surface. Water Quality in Konabari, BSCIC area at Gazipur, Bangladesh. International Research Journal of Environment Sciences, ISSN 23191414, 4(11), pp. 1-10.

Ferdous A., Kenneth J.T. (2001). Current constraints and future possibilities for Bangladesh fisheries. Food Policy, 26, pp. 297-313.

Food and Agricultural Organization, Soil Portal (1988). World Reference Base.

Giri C., Shrestha S. (1996). Land cover mapping and monitoring from NOAA AVHRR data in Bangladesh. Int. J. Remote Sens., 17, 2749-2759.

Hasan M., Hossain M., Bari M., Islam M. (2013). Agricultural Land Availability in Bangladesh; SRDI, Ministry of Agriculture: Dhaka, Bangladesh, p. 42, ISBN 978-984-33-6141-7.

Haq S., Rahman A., Mallik D. (2017). Population and Environment in Bangladesh. World Development Indicators database, World Bank, 15 December 2017.

Islam K., Jashimuddin M., Nath B., Nath T.K. (2018). Land use classification and change detection by using multi-temporal remotely sensed imagery: The case of Chunati wildlife sanctuary, Bangladesh. The Egyptian Journal of Remote Sensing and Space Science, 21, 37-47. doi: https://doi.org/10.1016/j.ejrs.2016.12.005

Klimanova O., Naumov A., Greenfieldt Y., Prado R.B., Tretyachenko D. (2017). Regional trends of land use and land cover transformation in Brazil in 2001-2012. Geography, Environment, Sustainability, 10(4), 98-116, doi: https://doi.org/10.24057/2071-9388-2017-10-4-98-116

Lambin E.F., Baulies X., Bockstael N., Fischer G., Krug T., Leemans R., Moran E.F., Rindfuss R.R., Sato Y., Skole D., Turner B.L., Vogel C. (1999). Land-use and land-cover change (LUCC): Implementation strategy. IGBP Report No. 48, IHDP Report No. 10, Stockholm, Bonn.

Lawrence B. Lesser. «Economic Reconstruction after Independence». A Country Study: Bangladesh (James Heitzman and Robert Worden, editors).

Leica Geosystems (2006). Erdas Imagine Tour Guides. USA: Leica Geosystems Geospatial Imaging.

López-Sánchez C.A. (2016). Evaluation of radiometric and atmospheric correction algorithms for aboveground forest biomass estimation using Landsat 5 TM data. Remote Sens., 8, 1-19, doi: http://dx.doi.org/10.3390/rs8050369

López-Serrano P.M., López-Sánchez C.A., Díaz-Varela R.A., Corral-Rivas J.J., Solís-Moreno R., Vargas-Larreta B., Álvarez-González J.G. (2015). Estimating biomass of mixed and unevenaged forests using spectral data and a hybrid model combining regression trees and linear models. iForest - Biogeosciences and Forestry 9, 226, doi: https://doi.org/10.3832/ifor1504008

Meyer W.B. and Turner B.L. (1994). Changes in Land Use and Land Cover: A Global Perspective. Cambridge University Press, Cambridge, UK. 
Millat-e-Mustafa M. (2002). A Review of Forest Policy Trends in Bangladesh -Bangladesh Forest Policy Trends. Policy Trend Report, 2002:114-121.

Ojima D.S., Galvin K.A., and Turner B.I. (1994). The global impact of land-use change. Bioscience 44, pp. 300-304.

Quasem M.A. (2011). Conversion of agricultural land to non-agricultural uses in Bangladesh: Extent and determinants. Bangladesh Dev. Stud., 34, pp. 59-85.

Rahman, A.A., Huq S., Haider R., Jansen E.G. (1994). Environment and Development in Bangladesh, The University Press Limited, Dhaka, Bangladesh.

Rahman L.M. (2000). The Sundarbans: a unique wilderness of the world. USDA Forest Service Proceedings RMRS-P-15-VOL-2, 143-148.

Rasheed S. (2008). Bangladesh Resource and Environmental Profile, AH Development Publishing House, Dhaka, Bangladesh.

Salam M.A., Noguchi T., and Koike M. (2005). Factors influencing the sustained participation of farmers in participatory forestry: a case study in central Sal forests in Bangladesh. Journal of Environmental Management, 74(1), 43-51.

Shalaby A. and Tateishi R. (2007). Remote sensing and GIS for mapping and monitoring land cover and land use changes in the Northwestern coastal zone of Egypt. Applied Geography, 27(1), 28-41.

Sultana M.S., Kulsum U., Shakila A. and Islam M.S. (2012). Toxic Metal Contamination on the River near Industrial Area of Dhaka. Universal Journal of Environmental research and Technology, 2(2), 56-64.

30 Structures Constructed Illegally along Turag River (2017, October 09). The Daily Star. https://www.thedailystar.net/country/30-structures-constructed-illegally-along-turagriver-gazipur-judicial-probe-report-1478797

Uddin K. and Gurung, D.R. (2010). Land cover change in Bangladesh - a knowledge based classification approach. In Proceedings of the 10th International Symposium on High Mountain Remote Sensing Cartography, ICIMOD, Kathmandu, Nepal, pp. 8-11.

Xin Z.B., Xu J.X., Zheng W. (2008b). Spatiotemporal variations of vegetation cover on the Chinese Loess Plateau (1981-2006): impacts of climate changes and human activities. Sci. China Ser. D: Earth Sci. 51 (1), 67-78.

Yang X. and Lo C.P. (2002). Using a time series of satellite imagery to detect land use and cover changes in the Atlanta, Georgia. International Journal of Remote Sensing, 23(9), 1775-1798. 